\title{
Healthy Eating: FOLATE ${ }^{1}$
}

Linda B. Bobroff ${ }^{2}$

\section{Why is folate important?}

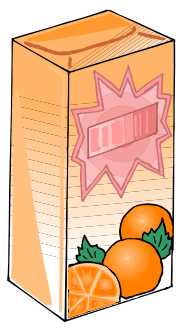

Folate is one of the B vitamins. Our bodies use folate to build proteins and to make new cells. Folate is especially important for women of childbearing age, pregnant and nursing women, growing children and older people.

If you don't get enough folate, you could develop anemia. You also could be at higher risk for heart disease, stroke, cancer, or memory problems.

How much folate do I need?

Older adults need 400 micrograms ( $\mu$ g) of folate a day.

Good Sources of Folate

\begin{tabular}{|l|c|}
\hline \multicolumn{1}{|c|}{ FOOD } & $\begin{array}{c}\text { FOLATE } \\
(\mu \mathrm{g})\end{array}$ \\
\hline Spinach, cooked, $1 / 2$ cup & 130 \\
\hline Kidney beans, cooked, 1 ² cup & 115 \\
\hline Fortified cereal, 1 serving & $100-400$ \\
\hline Peanuts, dry roasted, 1/2 cup & 80 \\
\hline Orange juice, 1 cup & 75 \\
\hline Romaine, shredded, 1 cup & 75 \\
\hline
\end{tabular}

\section{What foods contain folate?}

* Green leafy vegetables

* Orange juice

\& Beans and lentils

\& Peanuts

\& Fortified cereals and breads

If you do not get enough folate from the foods you eat, you may need to take a supplement.

Supplements contain a form of the vitamin called folic acid.

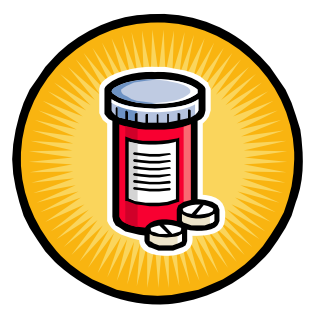

1. This publication is FCS8560, One of a series of the Department of Family, Youth and Community Sciences, Florida Cooperative Extension Service, Institute of Food and Agricultural Sciences, University of Florida. This leaflet was developed with funding from the Florida Department of Elder Affairs, in partnership with state, county and local agencies. Publication date: March 2000. Revised: February 2006. Please visit the EDIS Web site at http://edis.ifas.ufl.edu

2. Linda B. Bobroff, PhD, RD, LD/N, professor, Foods and Nutrition, Department of Family, Youth, and Community Sciences, Institute of Food and Agricultural Sciences, University of Florida, Gainesville, FL 32611-0310. Leaflet design by Paulina Wittkowsky, MS, RD, formerly with the Department of Family, Youth, and Community Sciences, University of Florida. 